\title{
The Association of Dopamine Receptor D2 (DRD2) and Vasoactive Intestinal Peptide (VIP) Polymorphisms on Egg Production in High Egg Strain of Pradu Hangdum Chiangmai Chickens
}

\section{Khanitta Ruangwittayanusorn ${ }^{1}$, Doungnapa Promket ${ }^{1 *}$, Kamonnate Pimrueng ${ }^{1}$, Jennarong KAMMONGKUN $^{2}$}

${ }^{1}$ Branch of Animal Science, Department of Agricultural Technology, Faculty of Technology, Mahasarakham University, Mahasarakham, 44150, Thailand; ${ }^{2}$ Bureau of Animal Husbandry and Genetic Improvement, Department of Livestock Development, Bangkok, 10400, Thailand.

\begin{abstract}
The objectives of the research were to determine the association of Dopamine Receptor D2 type (DRD2) and Vasoactive Intestinal Peptide (VIP) on egg production in 281 high egg strain of Pradu Hangdum Chiangmai chickens (HPHC). PCR-RFLP protocols were used to identify polymorphisms of both genes. The frequencies of TT, TC and CC genotypes of DRD2 were $0.05,0.40$, and 0.55 , respectively. The frequencies of $\mathrm{T}$ and $\mathrm{C}$ alleles of $D R D 2$ were 0.25 and 0.75 , respectively. Regarding VIP, the frequencies of II, ID and DD genotypes were $0.59,0.28$, and 0.13 , respectively. The frequencies of $\mathrm{I}$ and $\mathrm{D}$ alleles of VIP were 0.73 and 0.27 , respectively. The association of $D R D 2$ polymorphism were detected on egg number at 360 days $(\mathrm{EN} 360)$ and egg per month $(\mathrm{EM})(\mathrm{P}<0.05)$. The chickens carrying the CC genotype had higher EN360 and EM (189.82 eggs and 15.81 eggs) and the ones carrying the TC (180.98 eggs and $15.08 \mathrm{eggs})$ and the TT genotype (176.38 eggs and $14.69 \mathrm{eggs})$ was non-significant. The VIP polymorphism were associated on egg number at 270 days (EN270), EN360 and EM $(\mathrm{P}<0.01)$. The DD genotype had higher EN270, EN360 and EM when compared to the ID and II genotypes. The DRD2 and VIP genes were moderate polymorphism and their alleles could be the potential genetic markers for chickens' selection to improve egg number.
\end{abstract}

Keywords | Gene marker, Native chickens, Egg production, DRD2, VIP

Received | September 22, 2021; Accepted | November 14, 2021; Published | January 04, 2022

*Correspondence | Doungnapa Promket, Branch of Animal Science, Department of Agricultural Technology, Faculty of Technology, Mahasarakham University, Mahasarakham, 44150, Thailand; Email: napakran@hotmail.com

Citation | Ruangwittayanusorn K, Promket D, Pimrueng K, Kammongkun J (2022). The association of dopamine receptor D2 (DRD2) and vasoactive intestinal peptide $(V I P)$ polymorphisms on egg production in high egg strain of pradu hangdum chiangmai chickens. Adv. Anim. Vet. Sci. 10(2): $212-218$.

DOI | https://dx.doi.org/10.17582/journal.aavs/2022/10.2.212.218

ISSN (Online) | 2307-8316

\section{INTRODUCTION}

$\mathrm{N}$ ative chickens are important for rural households as a source of high-quality protein. The advantage characters are the ability to tolerate the harsh environmental condition and resistant to diseases (Padhi, 2016). Moreover, meat of native chicken has lower contents of fat and cholesterol (Jaturasitha et al., 2016; Bungsrisawat et al., 2018). Thai native and Thai native crossbred chicken showed high anserine anserine/carnosine antioxidant substances carcass and meat quality yields (Charoensin et al., 2021). Eggs are considered rich sources of protein and iron (Kusum et al., 2018). High egg strain of Pradu Hangdum Chiangmai chickens (HPHC) are a native chicken that the breeding objective is to increase egg production by joint cooperation between the Department of Livestock Development and the Agricultural Research Development agency (Public organization). Pradu Hangdum is one of four native chickens in Thailand, which maintain the flock in Chiang Mai Livestock Research and Breeding Center, the researchers aimed to improve egg production for produce more chick for the farmers. HPHC was developed from Pradu Hangdum Chiangmai 1, with meat quality and appearance characteristics that are preferred by consumers (Kammongkun et al., 2015). Therefore, the objective of breeding program was to increase 30\% egg production from $147 \mathrm{egg} / \mathrm{year}$ of foundation stock to $191 \mathrm{egg} / \mathrm{year}$ of breeding stock. The characteristics of Pradu Hangdum 
chickens are that they have a feather color of black, a small pea comb, color of face is red and whitish yellow skin (Kammongkun et al., 2015). Nowadays, consumers have an increasing demand for native chicken because of native chickens are generally raised without using antibiotics or chemicals, and thus are rendered safe and have no negative impact on human health (Funaro et al., 2014).

The limitations of native chickens are low egg production and slow growth. If the hens give higher egg production, the costs of chicks and costs of fattening will reduce. Therefore, genetic improvement has been made to improve the native chickens to increase egg production and growth performance. The selected chickens can growth better than non-selection in open housing (Promket and Ruangwittayanusorn, 2021). However, for egg production there are many ways to improve. The identification of polymorphism and DNA marker associated with egg production traits could be used as marker assisted selection (MAS) which lead to genetics improvement to increase egg production of native chickens.

In recent years, the molecular technologies and genetic marker approach have gradually become the mainstream for genetic improvement in breeding program. Furthermore, molecular breeding can significantly improve breeding efficiency and shorten the breeding period, so using molecular marker breeding has an advantage in breeding. Egg production has importance economic traits in poultry that are complex quantitative traits involving many genes and their interactions. Many researches focus on gene marker associated with egg production that can be used to improve egg production (Liu et al., 2019; Syed et al., 2019; Zhuang et al., 2019; Tenzin et al., 2020). From the research results, it was found that using molecular markers to selecting high egg production in chickens was success. Therefore, a molecular marker that influenced egg production in HPHC population was a good decision for genetic improvement to increase egg productions.

Dopamine, an abundant neurotransmitter in the central nervous system and periphery, has been shown to play important roles in cognition, emotion, endocrine function, and hyperprolactinemia in mammals (Xu et al., 2010a). Dopamine has five dopamine receptors subtypes (DRD1$D R D 5)$ have been classically divided into two classes referred to as D1-like (DRD1 and DRD5) and D2-like (DRD2, DRD3, and DRD4) receptors based on their pharmacological, biochemical, and physiological differences (Xu et al., 2010b). In avian, dopamine, played a critical role in prolactin secretion and stimulating prolactin secretion via dopamine receptors D1 at the hypothalamic level and inhibiting prolactin secretion via dopamine receptors D2 $(D R D 2)$ at the pituitary by operating through vasoactive intestinal peptide (Xu et al., 2010a). Prolactin is a negative regulator of avian reproductive activity such as incubating behavior. Inhibit pituitary secretion of prolactin by DRD2, inhibit incubation activities and to improve egg production in chickens.

Vasoactive intestinal peptide $(V I P)$ controls prolactin hormone by binds to specific receptors on the lactotroph cells in the anterior pituitary. Moreover, the protein level of VIP and gene expression correlate with circulating prolactin levels during the different reproductive stages and stimulate the secretion of prolactin and regulate prolactin (Zhou et al., 2010). Vasoactive intestinal peptide immunoneutralization reduces prolactin gene expression and prolactin secretion induced by electrical stimulation of the hypothalamus (Halawani et al., 2000). Association studies between variation of VIP gene and egg production traits have been carried out in poultry and found that five polymorphisms were associated with the total number of eggs in chickens (Zhou et al., 2010; Xu et al., 2011b; Ngu et al., 2015). Since there was no the information of DRD2 and VIP genes on egg production in Thai Native Chicken. Therefore, it would be required to study the association between gene markers on egg production will be benefit for genetic improvement in native chicken. The objective of this research was to identify the association of DRD2 and VIP genes on egg production traits in HPHC.

\section{MATERIALS AND METHODS}

\section{ETHICAL CONSIDERATION}

Institution Animal Care and Use Committee (IACUC) of Mahasarakham University, Mahasarakham, Thailand, approved the use of animals under this study (IACUCMSU-007/2020).

\section{ANIMALS AND EGG PRODUCTION RECORD}

In this study, a total of 281 at the age of sixteen weeks of HPHC were randomly selection under the open house at Chiangmai Livestock Research and Breeding Center, Sanpatong District, Chiangmai Province, Thailand. The chickens were provided feed and water ad libitum using commercial diet (17\% CP and 2,900 kcal of ME/ $\mathrm{kg}$ for laying period) (NRC, 1994). At 16 weeks of age, they were reared in separate cages $(8 \times 16$ inch). The individual data recording were composted with hen weight at first egg (HWFE), age at first egg (AFE), egg weight at first egg (EWFE), egg weight at 270 days (EW270), egg weight at 360 days (EW360), egg number at 270 days (EN270), egg number at 360 days (EN360) and egg per month (EM).

\section{BLOOD COLLECTION AND DNA EXTRACTION}

Blood samples $(1 \mathrm{~mL})$ were collected from the wing vein into a tube containing $100 \mu \mathrm{L}$ of $0.5 \mathrm{M}$ 
ethylenediaminetetraacetic acid (EDTA). This was used as an anticoagulant.

Genomic DNA was isolated from whole blood using the guanidine hydrochloride method (Goodwin et al., 2011). Briefly, cell lysis buffer and protein precipitation buffer were added to the blood. Cell lysate was then centrifuged for 5 minutes at $10,000 \mathrm{rpm}$ at $4^{\circ} \mathrm{C}$. The supernatant was then transferred to $1.5 \mathrm{~mL}$ tube, and absolute isopropanol was added. The DNA was precipitated at 10,000 rpm for 5 minutes at $4^{\circ} \mathrm{C}$. The supernatant was discarded, and DNA pellet was washed 2 times with $75 \%$ ethanol. The DNA pellet was air-dried at room temperature and dissolved in DNA hydration buffer. The DNA quality and concentration were determined by Nanodrop 2000c spectrophotometer (Thermo Scientific, USA). The DNA was diluted to $50 \mathrm{ng} /$ $\mu \mathrm{L}$ as a working solution and stored at $-20^{\circ} \mathrm{C}$ before use.

\section{PCR AMPLIFICATION}

The reactions of PCR mixture were carried out in a total volume of $10 \mu \mathrm{L}$ containing: $1 \mu \mathrm{L}$ of diluted genomic DNA $(50 \mathrm{ng} / \mu \mathrm{L}), 1 \mu \mathrm{L}$ of $10 \mathrm{X}$ PCR buffer, $0.8 \mu \mathrm{L}$ of $50 \mathrm{mM} \mathrm{MgCl}, 1 \mu \mathrm{L}$ of $1 \mathrm{mM}$ dNTPs, $1 \mu \mathrm{L}$ of $5 \mu \mathrm{M}$ of each primer, add $0.1 \mu \mathrm{L}$ of Taq DNA polymerase (Promega, San Diego, CA) and $4.1 \mu \mathrm{L}$ of nuclease free water. PCR amplification was carried out in a PCR thermal cycle (COBETT RECHEARCH, Australia 2003, iCycler thermal cycler, BioLad, U.S.A) conducted under the following conditions: Pre-heating at $94^{\circ} \mathrm{C}$ for 5 minutes followed by 35 cycles at denature $94^{\circ} \mathrm{C}, 30 \mathrm{~s}$; annealing temperature (Table 1), $40 \mathrm{~s}$; and extension $72^{\circ} \mathrm{C}$, $30 \mathrm{~s}$. Final extension was carried out at $72^{\circ} \mathrm{C}$ for 5 minutes and the amplified products were hold at $4^{\circ} \mathrm{C}$ until needed. The PCR product of DRD2 and VIP genes were analyzed using 2\% agarose gel. After electrophoresis at $100 \mathrm{~V}$ for 35 minutes, gel was stained with GELSTAR ${ }^{\mathrm{TM}}$ (Gelstar Inc, NY) for 10 minutes. DNA fragments were visualized by gel documentation (Lab Focus, Inc.).

\section{RESTRICTION FRAGMENT LENGTH POLYMORPHISM} (RFLP) ANALYSIS

Polymerase chain reaction (PCR) products from each chicken were digested separately with 1 restriction enzymes (BseGI for DRD2 and $V s p \mathrm{I}$ for $V I P$ ). Each digestion reaction contained $2 \mu \mathrm{L}$ of PCR products, $1 \mu \mathrm{L}$ of cut smart, and
$0.2 \mu \mathrm{L}$ of the restriction enzyme, add deionized water 6.8 $\mu \mathrm{L}$ in a total volume of $10 \mu \mathrm{L}$. Subsequently, each reaction was incubated overnight at $55^{\circ} \mathrm{C}$ for $B s e \mathrm{GI}$ and $37^{\circ} \mathrm{C}$ for $V_{s p} \mathrm{I}$. After digestion, the products were visualized by $2.5 \%$ agarose gel electrophoresis for 40 minutes, at $100 \mathrm{~V}$, and the genotypes were determined with Gel Documentation (Lab Focus, Inc.) by GELSTAR ${ }^{\mathrm{TM}}$ (Gelstar Inc, NY) staining.

\section{STATistical ANALYSis}

The means of egg production traits were analyzed by PROC MEANS (SAS Institute Inc. Cary, NC, 2003). Allele and genotype frequencies, polymorphism information content (PIC) and the Hardy-Weinberg equilibrium (HWE) were tested based on Chi-square test $(\chi 2)$ according with Falconer and Mackay (1996).

The associations between the genotypes of the candidate genes $(D R D 2$ and VIP) and diplotype on egg production were analyzed using the following model:

$$
Y_{i j}=\mu+G_{i}+e_{i j}
$$

Where; $Y_{i j}$ is phenotypic record (egg production traits) in the chickens, $\mu$ is the overall population mean, $G_{i}$ is the fixed effect of the genotype (DRD2 or VIP or diplotype) and $e_{i j}$ is the residual error.

\section{RESULTS AND DISCUSSION}

\section{EgG PRODUCTION IN HIGH EGg STRAIN OF PRADU HANGDUM CHIANGMAI CHICKENS (HPHC)}

The means (Means), standard deviation (SD), minimum (Min) and maximum (Max) of egg production traits in HPHC were presented in Table 2. Means of HWFE and EWFE were $1,928.99 \mathrm{~g}$ and $33.80 \mathrm{~g}$, respectively. The AFE was found at 153.89 days, cumulative of egg number at 270 days (EN270) and 360 days (EN360) were 150.34 and 185.70 eggs, respectively. Moreover, the EW270 and EW360 were $44.71 \mathrm{~g}$ and $44.80 \mathrm{~g}$, respectively.

\section{GENOTYPES AND ALLELE FREQUENCIES OF DRD2 AND VIP GENES IN HPHC}

Two candidate genes (DRD2 and VIP) were identified from HPHC. The PCR product of DRD2 and VIP were

Table 1: Sequences of primer and annealing temperatures (Ta) for PCR amplification.

\begin{tabular}{|c|c|c|c|c|c|c|c|}
\hline Genes & Location (bp) & Chr. ${ }^{3 /}$ & Gene ID & Primer sequence $\left(5^{\prime}-3^{\prime}\right)$ & Length $^{4 /}(\mathbf{b p})$ & $\mathrm{Ta}^{5 /}\left({ }^{\circ} \mathrm{C}\right)$ & Enzyme \\
\hline \multirow[t]{2}{*}{$D R D 2^{1 /}$} & T5841629C & Chr.24 & 428252 & F: tgcacataaaagcccactcactg & 248 & 60 & $B s e \mathrm{GI}$ \\
\hline & & & & R: gcctgagctggtgggggg & & & \\
\hline \multirow[t]{2}{*}{$V I P^{2 /}$} & \multirow{2}{*}{$\begin{array}{l}\text { AGG Indel } \\
\text { D2648-2650I }\end{array}$} & Chr.3 & 396323 & F: gaaacccatctcagtcatccta & 306 & 58 & $V s p \mathrm{I}$ \\
\hline & & & & R: accacctatttttccttttctac & & & \\
\hline
\end{tabular}

Note: ${ }^{1 /}$ Ngu et al. (2015); Xu et al. (2011a; b); ${ }^{2 /} \mathrm{Vu}$ and Ngu (2016); ${ }^{3 /}$ Chr. is chromosome ${ }^{4 /}$ Length is the length of PCR Products; ${ }^{5 /} \mathrm{Ta}$ is annealing temperature. 
Table 2: Means, standard deviations (SD), minimum (min) and maximum (max) values for egg production parameters.

\begin{tabular}{lllll} 
Traits & Means & SD & Min & Max \\
HWFE (g) & $1,928.99$ & 193.02 & $1,075.00$ & $2,482.00$ \\
\hline AFE (day) & 153.89 & 11.24 & 130.00 & 198.00 \\
EWFE (g) & 33.80 & 5.63 & 21.20 & 55.00 \\
EW270 (g) & 44.71 & 3.05 & 32.48 & 54.12 \\
EW360 (g) & 44.80 & 3.07 & 32.28 & 54.36 \\
EN270 (egg) & 150.34 & 32.72 & 53.00 & 221.00 \\
EN360 (egg) & 185.70 & 30.85 & 83.00 & 266.00 \\
EM (egg) & 15.47 & 2.57 & 6.92 & 22.17
\end{tabular}

Note: HWFE is hen weight at first egg, AFE is age at first egg, EWFE is egg weight at first egg, EW270 is egg weight at 270 days, EW360 is egg weight at 360 days, EN270 is egg number at 270 days, EN360 is egg number at 360 days and EM, egg per month.

$248 \mathrm{bp}$ and $306 \mathrm{bp}$ (Figures 1, 2), respectively. The single nucleotide polymorphism (SNP) of $D R D 2$ was transition mutations one nucleotide $(\mathrm{T}>\mathrm{C}$ or $\mathrm{C}>\mathrm{T})$, whereas $V I P$ was INDEL variations based on the addition or removal of AGG nucleotides (D2648-2650I). The PCR products were digested with $B s e \mathrm{GI}$ for $D R D 2$ and $V s p$ I for $V I P$. The RFLP pattern of three genotypes on $D R D 2$ were genotype TT

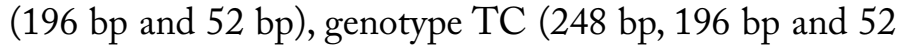
bp) and genotype CC (248 bp). While digestion with $V_{s p} \mathrm{I}$ of VIP were genotype II (306 bp), genotype ID (306 bp, $154 \mathrm{bp}$ and $152 \mathrm{bp}$ ) and genotype DD (154 bp and $152 \mathrm{bp}$ ).

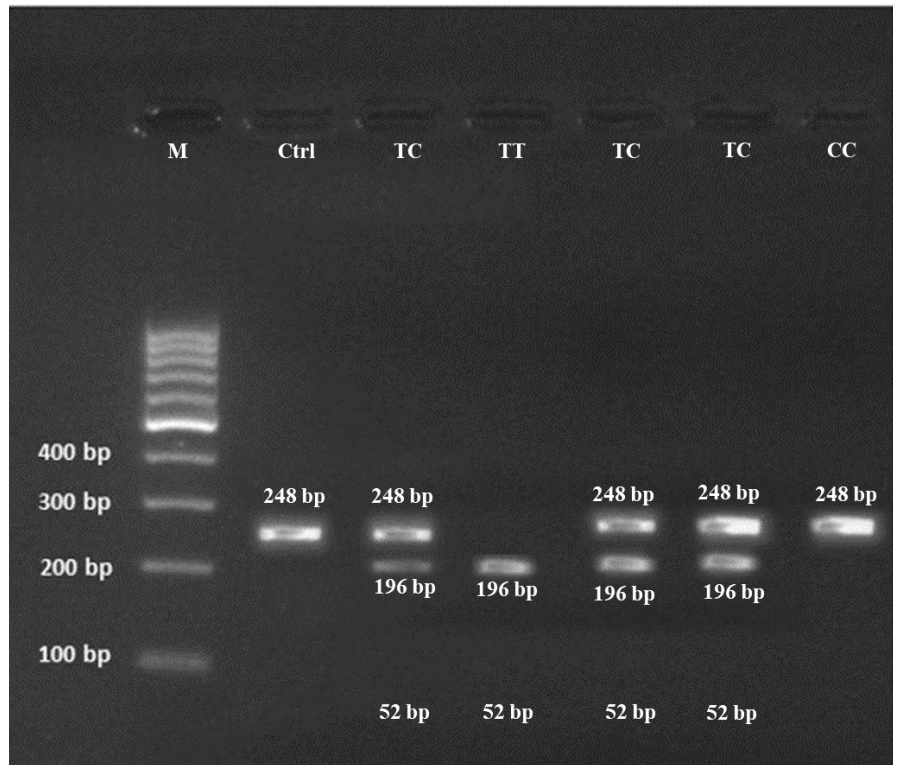

Figure 1: The genotype of $D R D 2$ gene: $\mathrm{M}=$ marker 100 bp, Ctrl = PCR product $(248 \mathrm{bp})$, genotype TT (196 bp and $52 \mathrm{bp}$ ), genotype TC (248 bp, $196 \mathrm{bp}$ and $52 \mathrm{bp}$ ) and genotype CC (248 bp) digested with $B s e \mathrm{GI}$.

The distribution of the genotype and allele frequencies are shown in Table 3. Three genotypes of DRD2 gene (TT, $\mathrm{TC}$ and $\mathrm{CC}$ ) were found with frequencies ranging from
0.05 to 0.55 and allele $\mathrm{T}(0.25)$ lower frequency than allele $\mathrm{C}$ (0.75). The allele frequencies of the VIP genes were observed for allele I (0.73) and allele $\mathrm{D}(0.27)$. For the $V I P$, the highest genotype frequency was II pattern (0.59) and genotype frequency for ID and DD were 0.28 and 0.13 , respectively (Table 3). The DRD2 and VIP are followed HWE and fitted the assumption of the equilibrium. The average polymorphism information content (PIC) value of DRD2 and VIP genes were 0.31 and 0.32 , respectively. Results showed that the DRD2 and VIP were moderate polymorphic in HPHC.

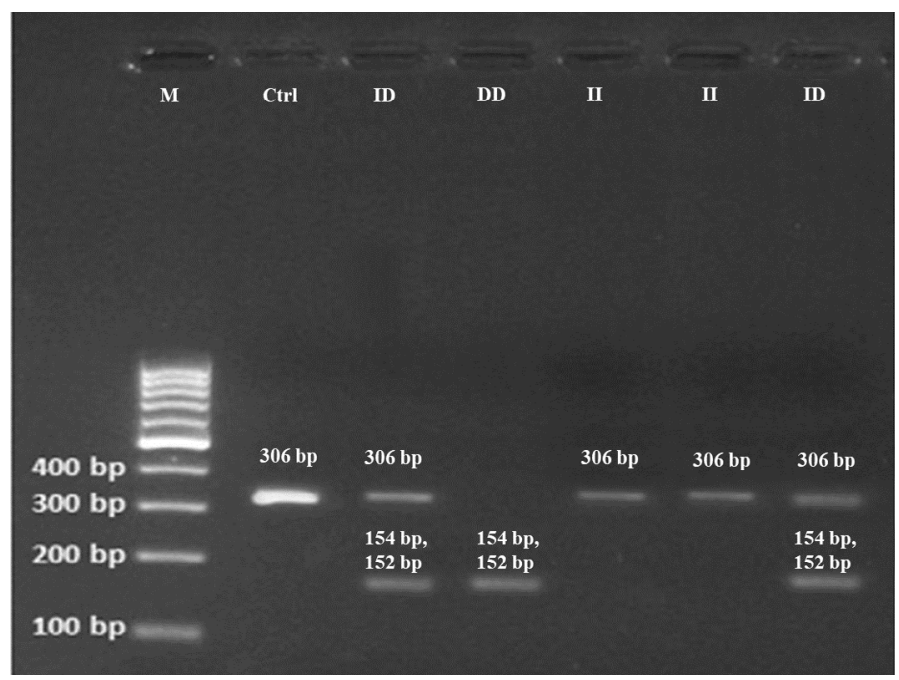

Figure 2: The genotype of VIP gene: $\mathrm{M}=$ marker $100 \mathrm{bp}$, Ctrl = PCR product, genotype II (306 bp), genotype ID (306 bp, $154 \mathrm{bp}$ and $152 \mathrm{bp}$ ) and genotype DD (154 bp and $152 \mathrm{bp}$ ) digested with $V_{s p} \mathrm{I}$.

Table 3: Genotype and allele frequencies of polymorphisms

\begin{tabular}{|c|c|c|c|c|c|c|c|c|}
\hline \multirow[t]{2}{*}{ Gene } & \multirow[t]{2}{*}{$\begin{array}{l}\text { To- } \\
\text { tal }\end{array}$} & \multicolumn{3}{|c|}{ Genotype frequency } & \multicolumn{2}{|c|}{$\begin{array}{l}\text { Allele } \\
\text { frequency }\end{array}$} & \multirow[t]{2}{*}{$\chi^{2}$} & \multirow[t]{2}{*}{ PIC } \\
\hline & & TT & $\mathrm{TC}$ & $\mathrm{CC}$ & $\mathrm{T}$ & $\mathrm{C}$ & & \\
\hline \multirow[t]{2}{*}{ DRD2 } & 281 & $\begin{array}{l}0.05 \\
(13)\end{array}$ & $\begin{array}{l}0.40 \\
(111)\end{array}$ & $\begin{array}{l}0.55 \\
(157)\end{array}$ & 0.25 & 0.75 & 0.08 & 0.306 \\
\hline & & II & ID & $\mathrm{DD}$ & I & $\mathrm{D}$ & & \\
\hline VIP & 281 & $\begin{array}{l}0.59 \\
(166)\end{array}$ & $\begin{array}{l}0.28 \\
(79)\end{array}$ & $\begin{array}{l}0.13 \\
(36)\end{array}$ & 0.73 & 0.27 & 0.12 & 0.321 \\
\hline
\end{tabular}

Note: PIC is polymorphism information content; $\chi 2(1,0.05)$ $=3.84$.

\section{AsSOCIATION OF POLYMORPHISMS IN THE DRD2 AND} VIP GENES WITH EGG PRODUCTION

Association of the polymorphisms in the two candidate genes with egg production in HPHC were analyzed and the results were shown in Table 4. The significant effects of DRD2 polymorphism were detected on EN360 and EM $(\mathrm{P}<0.05)$. The chickens carrying the CC genotype had a great of EN360 and EM than the ones carrying the TC and TT genotype. However, chicken with TC genotypes had EN360 and EM values were not different from TT 
genotypes. The CC genotype of DRD2 had high EN360 (189.82 eggs) than the TC and TT genotype (180.98 and 176.38 eggs, respectively). Moreover, the CC genotype gave EM was 15.81 eggs, which was greater than the TC and TT genotype, which gave the EM were 15.08 and $14.69 \mathrm{egg}$, respectively.

Table 4: Association between genotype of DRD2 and VIP gene on egg production.

\begin{tabular}{|c|c|c|c|c|c|}
\hline \multirow[t]{2}{*}{ Gene } & \multirow[t]{2}{*}{ Traits } & \multicolumn{3}{|c|}{ Genotype } & \multirow[t]{2}{*}{$P$-value } \\
\hline & & TT & TC & $\mathrm{CC}$ & \\
\hline \multirow[t]{8}{*}{ DRD2 } & HWFE (g) & 1964.77 & 1930.14 & 1925.04 & 0.77 \\
\hline & AFE (day) & 156.46 & 153.74 & 153.78 & 0.70 \\
\hline & EWFE (g) & 33.00 & 34.44 & 33.41 & 0.29 \\
\hline & EW270 (g) & 45.08 & 44.68 & 44.70 & 0.90 \\
\hline & EW360 (g) & 45.07 & 44.88 & 44.72 & 0.87 \\
\hline & EN270 (egg) & 150.76 & 151.08 & 149.79 & 0.94 \\
\hline & EN360 (egg) & $176.38^{\mathrm{b}}$ & $180.98^{b}$ & $189.82^{a}$ & 0.03 \\
\hline & EM (egg) & $14.69^{\mathrm{b}}$ & $15.08^{b}$ & $15.81^{\mathrm{a}}$ & 0.03 \\
\hline \multirow[t]{9}{*}{ VIP } & & II & ID & DD & $\mathrm{P}$-value \\
\hline & HWFE (g) & 1940.69 & 1903.89 & 1930.17 & 0.39 \\
\hline & AFE (day) & 153.10 & 155.43 & 154.13 & 0.28 \\
\hline & EWFE (g) & 33.81 & 33.65 & 34.04 & 0.88 \\
\hline & EW270 (g) & 44.95 & 44.30 & 44.51 & 0.28 \\
\hline & EW360 (g) & 45.04 & 44.41 & 44.56 & 0.28 \\
\hline & EN270 (egg) & $145.74^{\mathrm{B}}$ & $151.21^{\mathrm{B}}$ & $169.66^{\mathrm{A}}$ & 0.003 \\
\hline & EN360 (egg) & $181.88^{\mathrm{B}}$ & $185.26^{\mathrm{B}}$ & $204.33^{\mathrm{A}}$ & 0.005 \\
\hline & EM (egg) & $15.15^{\mathrm{B}}$ & $15.43^{\mathrm{B}}$ & $17.02^{\mathrm{A}}$ & 0.005 \\
\hline
\end{tabular}

Note: ${ }^{a b}$ means within a row with different superscripts different significant $(\mathrm{P}<0.05) .{ }^{\mathrm{AB}}$ means within a row with different superscripts different significant $(\mathrm{P}<0.01)$. HWFE is hen weight at first egg, AFE is age at first egg, EWFE is egg weight at first egg, EW270 is egg weight at 270 days, EW360 is egg weight at 360 days, EN270 is egg number at 270 days, EN360 is egg number at 360 days and EM, egg per month.

The highly significant association was found between the VIP and EN270, EN360 and EM (p<0.01). The DD genotype had higher EN270 (169.66 eggs) and EN360
(204.33 eggs) value compared to the ID (151.21 and 185.26 eggs) and the II genotypes (145.74 and 181.88 eggs). The association of VIP gene was found in EM. Chicken with DD genotype showed higher EM than ID and II genotype $(\mathrm{P}<0.01)$.

\section{AsSOCIATION BETWEEN THE DIPLOTYPES OF DRD2} AND VIP GENE ON EGG PRODUCTIONS

The DRD2 and VIP genes were the candidate genes that effected on egg production traits. Egg production traits are control by multiple genes. Therefore, the combine genotype between the DRD2 and VIP genes on egg production was studied. A total of $281 \mathrm{HPHC}$ with 9 diplotypes were obtained based on these three genotypes. Five diplotypes with frequencies greater than $5.0 \%$ were analyzed for association with egg production. The CC-II diplotype has the highest frequency with $33.50 \%$. The result showed the significant association between diplotype and EN270, EN360 and EM $(\mathrm{P}<0.01)$. The CC-DD diplotype had the highest EN360 (206.30 eggs) and EM (17.19 eggs). The others diplotype were non-significantly different among them (Table 5).

The egg production of HPHC in this study which similarly with previous study of Worawit et al. (1998) reported mean of weight at first egg of hen was 1,900 g. Moreover, Tongsiri et al. (2019) reported mean of body weight at first egg in Thai native chickens was $2.05 \mathrm{~kg}$ and egg weight at first egg was $36.94 \mathrm{~g}$. The average annual egg productions of Thai native chicken (Pradu Hangdum) were $117 \pm 41$ eggs (Mookprom et al., 2017). Previous studies found that candidate gene such as DRD2 and VIP genes had effect on egg productions in native chickens (Xu et al., 2011a; Ngu et al., 2015). The size of the DNA fragment from the RFLP technique in this study as same the reported by Ngu et al. (2015).Most alleles frequency was similar to those previously reported in Chinese native chickens (Ningdu Sanhuang) and Vietnam chickens (Noi chickens) (Xu et al., 2011a; Ngu et al., 2015). The PIC value is often used to measure the polymorphism of allele fragments.According to Ding et al. (2010), PIC $>0.50$ indicates a highly informative

Table 5: Association of the diplotype in DRD2 and VIP gene with egg productions.

\begin{tabular}{llllllllll}
$\begin{array}{l}\text { Diplo } \\
\text { type }\end{array}$ & $\mathbf{n}$ & \multicolumn{8}{c}{ Egg productions } \\
CC-DD & 23 & 1934.00 & 154.47 & 33.84 & 45.06 & 45.01 & $71.01^{\mathrm{A}}$ & $206.30^{\mathrm{A}}$ & $17.19^{\mathrm{A}}$ \\
CC-ID & 40 & 1876.20 & 156.42 & 33.04 & 44.13 & 44.21 & $152.37^{\mathrm{B}}$ & $190.87^{\mathrm{B}}$ & $15.90^{\mathrm{B}}$ \\
CC-II & 94 & 1943.94 & 152.48 & 33.45 & 44.85 & 44.87 & $143.50^{\mathrm{B}}$ & $185.34^{\mathrm{B}}$ & $15.44^{\mathrm{B}}$ \\
TC-ID & 37 & 1940.22 & 154.18 & 34.52 & 44.50 & 44.67 & $150.43^{\mathrm{B}}$ & $180.10^{\mathrm{B}}$ & $15.00^{\mathrm{B}}$ \\
TC-II & 62 & 1922.39 & 153.83 & 34.46 & 45.00 & 45.20 & $149.06^{\mathrm{B}}$ & $177.93^{\mathrm{B}}$ & $14.82^{\mathrm{B}}$ \\
P-value & & 0.44 & 0.46 & 0.66 & 0.63 & 0.62 & 0.007 & 0.001 & 0.001
\end{tabular}

Note: HWFE is hen weight at first egg, AFE is age at first egg, EWFE is egg weight at first egg, EW270 is egg weight at 270 days, EW360 is egg weight at 360 days, EN270 is egg number at 270 days, EN360 is egg number at 360 days and EM, egg per month. ${ }^{\mathrm{AB}}$ means within a row with different superscripts different significant $(\mathrm{P}<0.01)$. 
locus, $0.25<\mathrm{PIC}<0.50$ indicates a reasonably informative locus, and $\mathrm{PIC}<0.25$ indicates a slightly informative locus. In HPHC population, DRD2 and VIP were reasonably informative loci. In this study, allele $\mathrm{C}$ for $D R D 2$ gene and allele I for VIP gene were high proportion than allele $\mathrm{T}$ and D, respectively. According with $\mathrm{Xu}$ et al. (2010a, $2011 b$ ) report that frequency of $\mathrm{C}$ allele was higher than $\mathrm{T}$ allele in DRD2 gene. In addition, VIP gene also showed higher proportion of I allele (Ngu et al., 2015). In HPHC, allele and genotype frequencies of $D R D 2$ and $V I P$ follow the Hardy-Weinberg law due to these HPHC were $\mathrm{G}_{0}$ flock and selection for egg production traits. These were recruited from 800 chicks and selected by 2 -month cumulative egg production with a low selection intensity and using only phenotype selection. As a result, both genes were not affected by selection and were in HWE. From Kubota et al. (2019) explain that HWE was influenced by many factors, including selection, the rate of recombination and mutation, genetic drift, the mating system, population structure, and genetic linkage.

In the present study, we detected a significant difference between genotype and EN360 and EM for DRD2 gene. In a similar study, Ngu et al. (2015) showed the significant associations between genotype of DRD2 and VIP gene on egg numbers in indigenous Noi chickens. Moreover, Ningdu Sanhuang population detected polymorphisms associated of $D R D 2$ gene with egg number at 300 days of age, chickens with TT genotype were higher egg number at 300 days compared to that of the $\mathrm{CC}$ and TC genotypes (Xu et al., 2011b). Tenzin et al. (2020) found in Pradu Hangdam chickens that DRD2 was associated with egg weight at first egg, with TC and TT genotypes having higher breeding values than the $\mathrm{CC}$ genotype.

Moreover, we found that VIP genotype associated with EN270, EN360 and EM. Also, another study showed the 5 ' region of VIP gene was related to egg production (Zhou et al., 2010). On the other hand, Xu et al. (2011b) proved that the VIP gene was not significant associated with egg number at 300 days of age in chickens. The dopaminergic system plays an important role in the regulation of the avian reproductive system (Xu et al., 2010b). Vasoactive intestinal peptide is prolactin releasing factor in chicken, stimulates and regulates the secretion of prolactin hormone, that is an important role in incubation behavior in chickens (Zhou et al., 2010). Furthermore, dopamine was demonstrated to play a dual role in prolactin release by affecting VIP secretion, exerting its inhibitory effect via dopamine D2 receptor $(D R D 2)$.

Results of diplotype analysis also showed that it was associated with EN270, EN360 and EM. In the same way, $\mathrm{Xu}$ et al. (2011a) found that the seven diplotype were significant associated with age at first egg traits. The result of this study showed that the polymorphism of DRD2 and VIP gene which associated with egg number. Thus, $\mathrm{CC}$ genotype in the $\mathrm{DRD} 2$ gene, as well as DD genotype of the VIP gene, may be important genotype for high egg number in chickens.

\section{CONCLUSIONS AND RECOMMENDATIONS}

DRD2 and VIP were analyzed using the PCR-RFLP technique for detection of genotypes. This study found the $D R D 2$ polymorphism was associated with EN360 and EM, while VIP polymorphism was associated with EN270 EN360 and EM. Chickens with CC and DD genotype have better egg number in High Egg Strain of Pradu Hangdum Chiangmai chickens (HPHC). Therefore, these genes could be used as genetic marker for egg number to HPHC chicken breeding program.

\section{ACKNOWLEDGMENTS}

The research team would like to thank the branch of Animal science development fund 2020, Faculty of Technology, Mahasarakham University, Mahasakham, Thailand, for financial support and Chiangmai Livestock Research and Breeding Centre, Sanpatong District, Chiangmai Province, Thailand and Agricultural Research Development agency (Public organisation), for blood samples and the data, which were the main sources of evidence for this research.

\section{NOVELTY STATEMENT}

This is the first report to study the association of DRD2 and VIP genes in High Egg Strain of Pradu Hangdum Chiangmai pupulation.

\section{AUTHOR'S CONTRIBUTION}

DP: Study conception and design, analysis and interpretation of results, draft manuscript preparation, reviewed the results and approved the final version of the manuscript.

KP: Collected egg production data and chicken blood samples, DNA extraction and genotype analysis

KR: Analysis and interpretation of results, approved the final version of the manuscript.

JK: Collected egg production data and chicken blood samples, approved the final version of the manuscript.

\section{CONFLict OF INTEREST}

The authors have declared no conflict of interest. 


\section{REFERENCES}

Bungsrisawat P, Sornthep T, Wiriya L, Sasitorn N, Panwadee S (2018). Genetic parameters of some carcass and meat quality traits in Betong chicken (KU line). J. Agric. Nat. Res., 52: 274-279. https://doi.org/10.1016/j.anres.2018.09.010

Charoensin S, Banyat L, Wuttigrai B, Jutarop P, Myra OV, Hiroko I, Monchai D (2021). Thai native chicken as potential functional meat source rich in anserine, anserine/ carnosine, and antioxidant substances. J. Anim., 11: 1-13. https://doi.org/10.3390/ani11030902

Ding FX, Zhang GX, Wang JY, Yuan L, Zhang LJ, Yue W, Wang HH, Li Z, Hou Z (2010). Genetic diversity of a Chinese native chicken breed, bian chicken, based on twenty-nine microsatellite markers. Asian Aust. J. Anim. Sci., 2: 154 161. https://doi.org/10.5713/ajas.2010.90367

Falconer DS, and Mackay TFC (1996). Introduction to quantitative genetics, Ed 4. Longmans Green, Harlow, Essex, UK.

Funaro A, Cardenia V, Petracci M, Rimini S, RodriguezEstrada MT, Cavani C (2014). Comparison of meat quality characteristics and oxidative stability between conventional and free-range chickens. J. Poult. Sci., 93: 1511-1522. https://doi.org/10.3382/ps.2013-03486

Goodwin W, Linacre A, Hadi S (2011). An introduction to forensic genetics (Vol. 2), John Wiley Sons.

Halawani MEEl, Whiting SE, Silsby JL, Pitts GR, Chaiseha Y (2000). Active immunization with vasoactive intestinal peptide in turkey hens. J. Poult. Sci., 79: 349-354. https:// doi.org/10.1093/ps/79.3.349

Jaturasitha S, Chaiwang N, Kreuzer M (2016). Thai native chicken meat: An option to meet the demands for specific meat quality by certain groups of consumers. A review. J. Anim. Prod. Sci., 57: 1582-1587. https://doi.org/10.1071/ AN15646

Kammongkun J, Prapasawat C, Leotaragul A (2015). Establishment foundation stock of chee-thapra breed of Thai native chickens. J. Khon Kaen Agric. 43 (SUPPL), 2.

Kubota S, Vandee A, Keawnakient P, Molee W, Yongsawatdikul J, Molee A (2019). Effects of the MC4R, CAPN1, and ADSL genes on body weight and purine content in slowgrowing chickens. J. Poult. Sci., 98: 4327-4337. https://doi. org/10.3382/ps/pez262

Kusum M, Verma RC, Renu M, Jain Hk, Deepak S (2018). A review: Chemical composition and utilization of egg. Int. J. Chem. Study, 6(3): 3186-3189.

Liu Z, Ning Y, Yiyuan Y, Guangqi L, Aiqiao L, Guiqin W, Congjiao S (2019). Genome-wide association analysis of egg production performance in chickens across the whole laying period. J. BMC Genet., https://doi.org/10.1186/ s12863-019-0771-7

Mookprom S, Boonkum W, Kunhareang S, Siripanya S, Duangjinda M (2017). Genetic evaluation of egg production curve in Thai native chickens by random regression and spline models. J. Poult. Sci., 96: 274-281. https://doi. org/10.3382/ps/pew326

Ngu NT, Nguyen HX, Chau TV, Nguyen TA, Tran ND, Nguyen THN (2015). Effects of Genetic Polymorphisms on egg production in Indigenous Noi Chicken. J. Exp. Biol. Agric. Sci., 3(VI).

NRC (National Research Council) (1994). Nutrition requirements of poultry. $9^{\text {th }}$ ed. National Academy Press, Washington D.C.
Padhi MK (2016). Importance of indigenous breeds of chicken for rural economy and their improvements for higher production performance. Scientifica, https://doi. org/10.1155/2016/2604685

Promket D, Ruangwittayanusorn K (2021). The comparatives of growth and carcass performance of the Thai native chicken between economic selection (Chee KKU12) and natural selection (Chee N). J. Vet. Int. Sci., 19(2): 247-257. https:// doi.org/10.12982/VIS.2021.022

SAS University Edition (2003). SAS Institute Inc., Cary, NC, USA

Syed AA, Ali AB, Abdullah IO, Shuai M, Chenghao S, Zhongdong H, Meikuen Z, Shuhong Z, Shijun L (2019). Novel Polymorphisms in RAPGEF6 Gene Associated with Egg-Laying Rate in Chinese Jing Hong Chicken using Genome-Wide SNP Scan. J. Genes, 10: 384. https://doi. org/10.3390/genes10050384

Tenzin J, Chankitisakul V, Boonkum W (2020). Association of polymorphisms of physiological candidate genes with phenotype and estimated breeding values of reproductive and growth traits in Thai indigenous chickens. J. Genet. Mol. Res., 19(1): 1-12. https://doi.org/10.4238/gmr18504

Tongsiri S, Gilbert MJ, Susanne H, Julius HJW, Li L, Theerachai C (2019). Genetic parameters and inbreeding effects for production traits of Thai native chickens. Asian Aust.J. Anim Sci., 32: 930-938. https://doi.org/10.5713/ajas.18.0690

Vu CT, Ngu NT (2016). Single nucleotide polymophisms in candidate genes associated with egg production traits in native noi chicken of vietnam. J. Plant Anim. Environ. Sci., 6: 162-169.

Worawit W, Suk W, Saim K, Banjub H (1998). A comparative study on egg production of 4 commercial hybrid layer strains. 33(8): 1-35.

Xu H, Shen X, Zhou M, Fang M, Zeng H, Nie Q, Zhang X (2010b). The genetic effects of the dopamine $\mathrm{d} 1$ receptor gene on chicken egg production and broodiness traits. J. BMC Genet., pp. 1-10. https://doi.org/10.1186/14712156-11-17

Xu H, Zeng H, Luo C, Zhang D, Wang Q, Sun L, Yang L, Zhou M, Nie Q, Zhang X (2011a). Genetic effects of polymorphisms in candidate genes and the QTL region on chicken age at first egg. J. BMC Genet., pp. 1471-2156. https://doi.org/10.1186/1471-2156-12-33

Xu HP, Shen X, Zhou M, Luo CL, Kang L, Liang Y, Zeng H, Nie QH, Zhang DX, Zhang XQ (2010a). The dopamine $\mathrm{d} 2$ receptor gene polymorphisms associated with chicken broodiness. J. Poult. Sci., 89: 428-438. https://doi. org/10.3382/ps.2009-00428

Xu HP, Zeng H, Zhang DX, Jia XL, Luo CL, Fang MX, Nie QH, Zhang XQ (2011b). Polymorphisms associated with egg number at 300 days of age in chickens. J. GMR., 10(4): 2279-2289. https://doi.org/10.4238/2011.October.3.5

Zhou M, Du Y, Nie Q, Liang Y, Luo C, Zeng H, Zhang X (2010). Associations between polymorphisms in the chicken VIP gene egg production and broody traits. J. Poult. Sci., pp. 195-203. https://doi.org/10.1080/00071661003745786

Zhuang L, Ning Y, Yiyuan Y, Guangqi L, Aiqiao L, Guiqin W, Congjiao S (2019). Genome-wide association analysis of egg production performance in chickens across the whole laying period. J. BMC Genet., 20: 67. https://doi.org/10.1186/ s12863-019-0771-7 